\title{
Changes in the Abundance and Composition of Phytoplankton in a Coastal Lagoon during Neap-Spring Tide Conditions
}

\author{
María Fernanda Gracia-Escobar ${ }^{1}$, Roberto Millán-Núñez ${ }^{{ }^{*}}$, \\ Adriana González-Silvera ${ }^{1}$, Eduardo Santamaría-del-Ángel ${ }^{1}$, \\ Víctor F. Camacho-Ibar ${ }^{2}$, Charles C. Trees ${ }^{3}$ \\ ${ }^{1}$ Facultad de Ciencias Marinas, Universidad Autónoma de Baja California, Ensenada, México \\ ${ }^{2}$ Instituto de Investigaciones Oceanológicas, Universidad Autónoma de Baja California, Ensenada, México \\ ${ }^{3}$ NATO Undersea Research Centre, La Spezia, Italy \\ Email: *rmillan@uabc.edu.mx, mgracia@uabc.edu.mx, adriana.gonzalez@uabc.edu.mx, \\ santamaria@uabc.edu.mx, vcamacho@uabc.edu.mx, trees@nurc.nato.int
}

Received 23 November 2013; revised 2 January 2014; accepted 19 January 2014

Copyright (C) 2014 by authors and Scientific Research Publishing Inc.

This work is licensed under the Creative Commons Attribution International License (CC BY).

http://creativecommons.org/licenses/by/4.0/

cc) (i) Open Access

\section{Abstract}

The objective of this work was to estimate the changes in abundance and composition of phytoplankton in a coastal lagoon in Baja California, México during neap-spring tide conditions. Sampling was conducted from the $7^{\text {th }}$ to the $16^{\text {th }}$ of October 2004 . Surface water was collected at 18 stations distributed across the bay during day time at high tide. Also, a time series was collected at a fixed station; surface water was collected every two hours from 8:00 to 18:00. High temperatures, low salinities and low nutrient concentrations at the oceanic end indicated weak or non upwelling conditions during this period. The phytoplankton community was characterized using an inverted microscope and the chemical taxonomy program CHEMTAX, based on pigment concentration estimated by high performance liquid chromatography (HPLC). The phytoplankton concentration was two times lower during this period than during periods of upwelling in the same year. Cryptophytes and diatoms were the most abundant groups estimated by CHEMTAX. Statistical analyses of the effect of tidal conditions on phytoplankton composition indicate that Zone A is strongly affected by tides, and that tidal effects are lessened at the inner zones. Differences in phytoplankton abundance between zones and between tidal conditions indicate that phytoplankton distribution is patchy in the lagoon.

*Corresponding author.

How to cite this paper: Gracia-Escobar, M.F., Millán-Núñez, R., González-Silvera, A., Santamaría-del-Ángel, E., CamachoIbar, V.F. and Trees, C.C. (2014) Changes in the Abundance and Composition of Phytoplankton in a Coastal Lagoon during Neap-Spring Tide Conditions. Open Journal of Marine Science, 4, 80-100. http://dx.doi.org/10.4236/ojms.2014.42010 


\section{Keywords}

\section{Phytoplankton; HPLC Pigments; CHEMTAX; Tides; Coastal Lagoon}

\section{Introduction}

Among other reasons, the distribution and abundance of phytoplankton in coastal lagoons have been studied to determine their usefulness for the growth of organisms in culture, as in the case of San Quintin Bay (SQB), a tidally dominated coastal lagoon with oyster cultures. Studies of phytoplankton abundance in SQB at spatial and temporal scales have been sporadic and mostly during spring and summer seasons [1]-[5]. These studies allowed describing changes in the abundance and composition of phytoplankton that occur within the lagoon.

The abundance and composition of phytoplankton communities in marine environments have been studied using inverted microscopy [6] [7]. The advantage of the microscopy method is the capability of identifying species, revealing morphological characteristics of each species, such as individual cell size, shape, the presence of colonies, spore formation, and association with other species [8]. However, this method is time consuming and requires taxonomy expertise. Mackey et al. [9] proposed the Chemical Taxonomy (CHEMTAX) program to estimate the composition of the phytoplankton community using the concentration of chlorophyll $a$ (Chla) and accessory pigments derived from HPLC analysis. Phytoplankton contains different pigments, some are "specific" to one phytoplankton group and others are "characteristic" because they are present in various phytoplankton groups [10] [11].

In SQB, most of the studies on pigments have focused on Chla measured by spectrophotometry or fluorometry [2] [4] [12] [13]. Phytoplankton abundance has mostly been evaluated by microscopy [1] [2] [4], and only one published study of phytoplankton abundance and composition has been based on HPLC pigments [3]. Most of the studies in SQB have been carried out in spring-summer during upwelling events, and no studies have been reported for the autumn season, when upwelling is weak or absent. Considering the strong physical dynamics of SQB and the lack of data during autumn, the objective of this work was to estimate the effect of tidal conditions (neap, transition and spring) on the distribution, abundance and composition of phytoplankton in SQB.

\section{Methodology}

\subsection{Study Area}

San Quintín Bay is a coastal lagoon located on the Pacific coast of Baja California, Mexico, between $30^{\circ} 24^{\prime}$ and $30^{\circ} 30^{\prime} \mathrm{N}$ and $115^{\circ} 57^{\prime}$ and $116^{\circ} 01^{\prime} \mathrm{W}$ (Figure 1). It is a "Y" shaped coastal lagoon with an approximate area of 42 $\mathrm{km}^{2}$ divided in two arms: the western arm is named Bahía Falsa and the eastern arm is named Bahía San Quintín [14]. SQB is a hypersaline system in which the salinity increases from the mouth inward due to the high evaporation rate and the lack of rainfall and surface runoff [2] [15]. Tides are mixed semidiurnal with average amplitude of $1.6 \mathrm{~m}$, with a maximum of $2.5 \mathrm{~m}$ during spring tides, providing an intense water exchange with the ocean. Due both to shallow depths and turbulence caused by tidal currents, there are not significant vertical gradients in the seawater properties [2] [16]. SQB is influenced by upwelling associated with the California Current system, which is largely produced by regional winds, especially towards the end of spring and during the summer [17] [18]. In the vicinity of SQB, tidal currents play an important role in the dynamics and ocean-lagoon exchange, transporting nutrient-rich waters into the lagoon [2]. The combination of tidal currents and upwelling events explains the presence of low-temperature and high-nutrient concentration water in the inner lagoon [2] [16], promoting high phytoplankton production [17].

\subsection{Sampling}

Two types of sampling were conducted between the $7^{\text {th }}$ and $16^{\text {th }}$ of October 2004 during the progression from neap to spring tide conditions. The first one was a spatial sampling, consisting of a network of 18 stations sampled over two days during day time and high tide on October $6^{\text {th }}$ to $8^{\text {th }}$ (neap tide), October $11^{\text {th }}$ and $12^{\text {th }}$ (transition tide) and on October $14^{\text {th }}$ and $15^{\text {th }}$ (spring tide). To facilitate data description SQB was divided in three zones: zone A (ocean-mouth), zone B (eastern arm) and zone C (western arm) (Figure 1). The second type of 


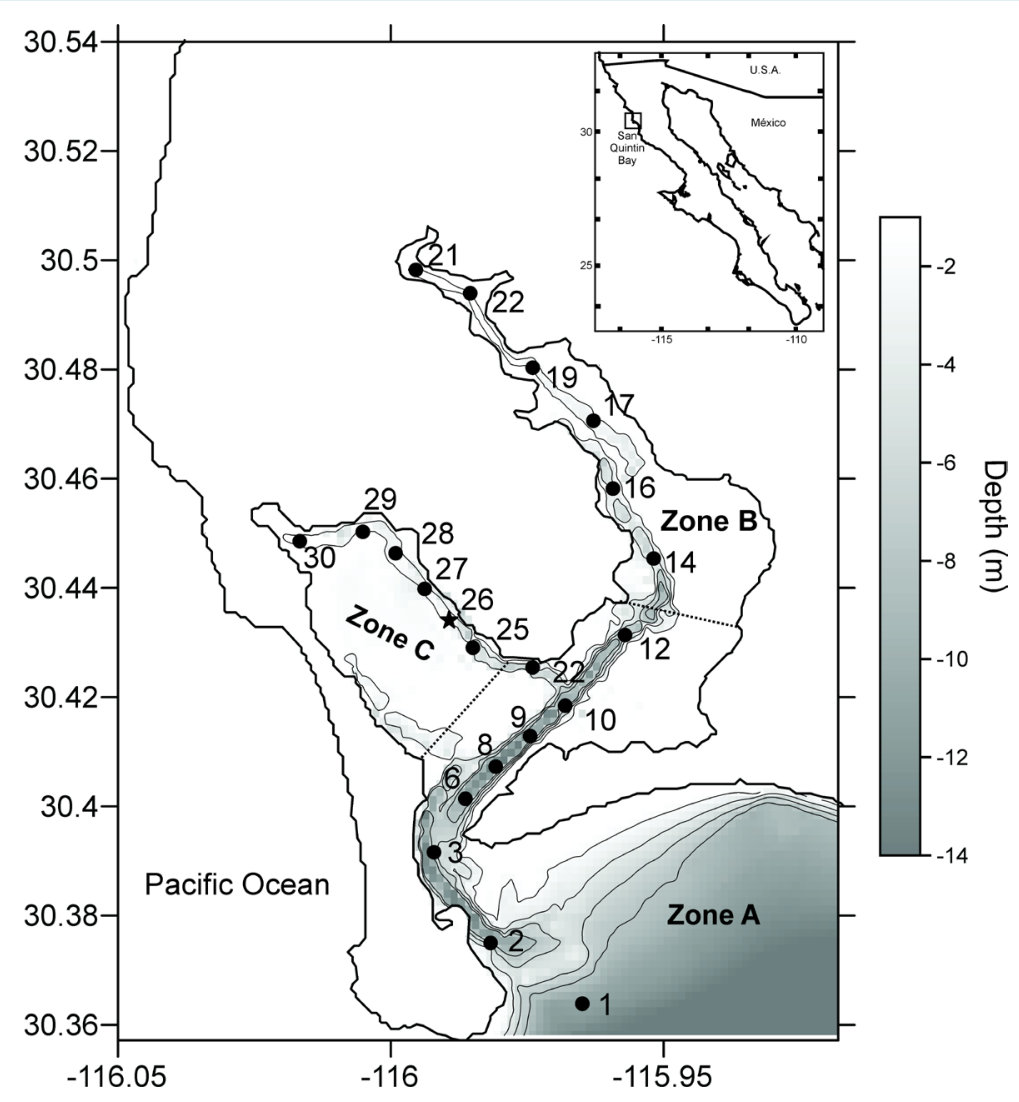

Figure 1. Study area and position of stations. Sampling zone is divided in: ocean mouth (zone A), eastern arm (zone B) and western arm (zone C). Station 26, indicated with a star, is the fixed station for time series.

sampling was a time series performed by collecting samples every two hours from 8:00 to 18:00 from the $7^{\text {th }}$ to the $16^{\text {th }}$ of October at station 26, located at the main channel on the western arm (Figure 1). In both types of sampling seawater samples were collected using a Van Dorn bottle approximately at $0.40 \mathrm{~m}$ depth. In the spatial sampling water samples were taken to determine temperature, salinity, nutrients, pigments and phytoplankton abundance and composition. In the time series station water samples were taken to determine pigments and phytoplankton abundance and composition. In this station a CTD (Ocean Sensors OS200) was attached to a float and deployed at $0.40 \mathrm{~cm}$ depth, recording salinity and temperature for the entire study period. Tidal height was obtained from data reported by CICESE (www.cicese.mx) referenced to mean sea level. Water temperature at each station was measured using a bucket thermometer $\left( \pm 0.1^{\circ} \mathrm{C}\right)$ and salinity using a Beckman salinometer.

\subsection{Phytoplankton Analysis}

For phytoplankton analysis, $250 \mathrm{ml}$ of seawater was collected in dark high-density polyethylene Nalgene bottles. An iodine neutral solution with a sodium acetate base (1:100 v: v) was added to each sample. Phytoplankton abundance was determined using an inverted microscope [6], in $25 \mathrm{ml}$ subsamples analyzed after $24 \mathrm{~h}$ of sedimentation. Total chamber bottom was counted and identified with a Karl Zeiss phase-contrast inverted microscope. Larger nanophytoplankton $(>5 \mu \mathrm{m})$ and abundant microphytoplankton $(>20 \mu \mathrm{m})$ were counted and identified at $400 \times$ and $200 \times$. Taxa larger than $30 \mu \mathrm{m}$ and less abundant cells were counted at $100 \times$ [19]. For organisms found in colonies or chains, individual cells were counted.

\subsection{HPLC Analysis}

For the pigment analysis, $600 \mathrm{ml}$ of seawater were filtered through a $25 \mathrm{~mm}$ diameter GF/F filter. Filters were wrapped in aluminum foil and stored in liquid nitrogen until laboratory analysis. Pigments were extracted using 
$100 \%$ acetone for $24 \mathrm{~h}$ in a freezer at $-20^{\circ} \mathrm{C}$. Pigment extracts were filtered with $0.2 \mu \mathrm{m}$ Acrodisc filters and injected into a Thermo Quest HPLC system with membrane degasser and Spherisorb ODS-2, C18 column (250 × $4.6 \mathrm{~mm}, 5.0 \mu \mathrm{m}$ particle size). A three-solvent gradient system was used following the methodology described by Bidigare and Trees [20]: (a) 80:20 methanol: 0.5 M ammonium acetate (v/v), (b) 90:10 acetonitrile: water (v/v) and (c) ethyl acetate, at a flow rate of $1 \mathrm{ml} \cdot \mathrm{min}^{-1}$. Canthaxanthin was used as an internal standard. The HPLC pigment standards were purchased from Sigma-Aldrich and DHI. Pigment standards were quantified with a spectrophotometer using published extinction coefficients [21]. Pigment standards were used to identify pigment peaks and to calibrate pigment concentrations based on the peak areas. Dichromatic equations reported in Latasa et al. [22] were used to spectrally resolve divinyl chlorophyll $a$ from monovinyl chlorophyll $a$.

\subsection{Phytoplankton Abundance Estimated by Chemtax}

The contribution of each phytoplankton group to total Chla (TChla) was assessed using the CHEMTAX program [9]. TChla is the sum of the concentrations of chlorophyllide $a$, Chla allomere and epimer, monovinyl and divinyl Chla obtained by HPLC. CHEMTAX uses three matrices: (1) a matrix containing the pigment concentrations in the samples, (2) an initial matrix containing the accessory pigment: Chla ratio for algal groups present in the sample and (3) a matrix that defines the limits of the accessory pigment:Chla ratios. Matrix 2 includes phytoplankton groups previously detected by microscope in SQB (Table 1). The ratios of accessory pigment: Chla used are based on previous reports for the SQB [3] and other places [9] [23].

\subsection{Nutrient Analysis}

Water samples for nitrate (plus nitrite) and phosphate determinations were filtered in the field through Whatman $25 \mathrm{~mm}$ GF/F pre-combusted filters onto $30 \mathrm{~mL}$ polycarbonate vials and stored frozen until analyzed. Nutrient determinations were performed with a Skalar SAN plus segmented-flow automated nutrient analyzer, based on the World Ocean Circulation Experiment (WOCE) protocols described in Gordon et al. [24], whereby nitrate (plus nitrite) determination is based on the sulfanilamide and N-1-N-diamine reactions [25] and phosphate determination is based on the molybdic acid and hydrazine reactions [26]. The precision and accuracy was determined by repeated measurements of intermediate calibration standards. Typical limits of detection are $\sim 0.1 \mu \mathrm{M}$ for nitrate and $\sim 0.05 \mu \mathrm{M}$ for phosphate.

\subsection{Statistical Analysis}

Correlation analysis was performed to obtain a matrix of Pearson's correlation coefficients and p values for each data pair of phytoplankton abundance estimated by microscope, phytoplankton group abundance estimated by CHEMTAX, and pigment concentrations. Also, one-way analyses of variance (ANOVA) were used to determine the effects of tidal conditions (neap, transition and spring) on dependent variables (temperature, salinity, nitrate, phosphate, TChla and phytoplankton group abundance estimated by CHEMTAX). For variables that were significantly affected by tidal conditions a multiple comparison Kruskas Wallis analysis was performed ( $\alpha$ $=0.05)$.

\section{Results}

\subsection{Spatial Sampling}

\subsubsection{Hydrographic Conditions}

In zone $\mathrm{A}$, temperature ranged from $15.3^{\circ} \mathrm{C}$ to $21.0^{\circ} \mathrm{C}$, tending to increase from the mouth toward the inner bay (Figure 2(a)). Temperature ranged from $18.2^{\circ} \mathrm{C}$ to $22.1^{\circ} \mathrm{C}$ in zone $\mathrm{B}$ and $18.2^{\circ} \mathrm{C}$ to $20.1^{\circ} \mathrm{C}$ in zone $\mathrm{C}$, and tends to increase toward the innermost areas. Salinity in zone A varied between 33.2 and 34.2, from 33.4 to 36.2 in zone B and from 33.4 to 34.2 in zone C, with a tendency to increase toward the interior of each zone (Figure 2(b)). Nitrate concentrations in zone A ranged from undetectable values to $2.1 \mu \mathrm{M}$ with a tendency to increase to the end of the zone. For zones B and C nitrate decreased toward the inner ends from 2.5 to $0.25 \mu \mathrm{M}$ and 1.9 to $0.5 \mu \mathrm{M}$ respectively (Figure 2(c)). Phosphate concentrations show values from 0.5 to $1.6 \mu \mathrm{M}$ for zone A, 1.5 to 1.9 for zone B and 1.0 to $1.7 \mu \mathrm{M}$ for zone C, with a tendency to increase from the mouth to the end of each arm (Figure 2(d)). 
Table 1. Input pigment:chlorophyll ratio for CHEMTAX analysis (a), and output pigment chlorophyll ratio from CHEMTAX calculation, spatial (b) and time series (c). Chlc3, chlorophyll c3; Chl c2, chlorophyll c2; Peri, peridinin; But, 19’ Butanoloxyfucoxanthin; Fuco, fucoxanthin; Prasi, prasinoxanthin; Viol, violoxanthin; Hex, 19' Hexanoloxyfucoxanthin; Diad, diadinoxanthin; Allo, Aloxanthin; Diat, diatoxanthin; Zea, zeaxanthin; Lut, lutein; Chl b, chlorophyll b; and DvChla, divinyl chlorophyll $a$.

\begin{tabular}{|c|c|c|c|c|c|c|c|c|c|c|c|c|c|c|c|}
\hline (a) & Chlc3 & Chlc2 & Peri & But & Fuco & Prasi & Viol & Hex & Diad & Allo & Diat & Zea & Lut & Chlb & DvChla \\
\hline Diatoms & & 0.287 & & & 0.400 & & & & 0.126 & & 0.035 & & & & \\
\hline Dinoflagellates & & 0.034 & 0.155 & & & & & & 0.114 & & 0.027 & & & & \\
\hline Haptophytes & 0.056 & 0.136 & & 0.003 & 0.217 & & & 0.255 & & & 0.031 & & & & \\
\hline Chlorophytes & & & & & & & & & & & & 0.003 & 0.011 & 0.247 & \\
\hline Chryptophytes & & 0.085 & & & & & & & & 0.172 & & & & & \\
\hline Prasinophytes & & & & & & 0.092 & 0.070 & & & & & & 0.004 & 0.500 & \\
\hline Cyanophytes & & & & & & & & & & & & 0.283 & & & \\
\hline Prochlorophytes & & & & & & & & & & & & 0.146 & & & 1.0 \\
\hline \multicolumn{16}{|l|}{ (b) } \\
\hline Diatoms & & 0.078 & & & 0.380 & & & & 0.034 & & 0.073 & & & & \\
\hline Dinoflagellates & & 0.032 & 0.18 & & & & & & 0.107 & & 0.025 & & & & \\
\hline Haptophytes & 0.046 & 0.093 & & 0.002 & 0.149 & & & 0.164 & & & 0.022 & & & & \\
\hline Chlorophytes & & & & & & & & & & & & 0.002 & 0.008 & 0.195 & \\
\hline Chryptophytes & & 0.057 & & & & & & & & 0.183 & & & & & \\
\hline Prasinophytes & & & & & & 0.074 & 0.056 & & & & & & 0.003 & 0.399 & \\
\hline Cyanophytes & & & & & & & & & & & & 0.220 & & & \\
\hline Prochlorophytes & & & & & & & & & & & & 0.068 & & & 0.466 \\
\hline \multicolumn{16}{|l|}{ (c) } \\
\hline Diatoms & & 0.070 & & & 0.347 & & & & 0.052 & & 0.016 & & & & \\
\hline Dinoflagellates & & 0.026 & 0.11 & & & & & & 0.085 & & 0.020 & & & & \\
\hline Haptophytes & 0.034 & 0.082 & & 0.002 & 0.132 & & & 0.118 & & & 0.019 & & & & \\
\hline Chlorophytes & & & & & & & & & & & & 0.002 & 0.009 & 0.156 & \\
\hline Chryptophytes & & 0.063 & & & & & & & & 0.223 & & & & & \\
\hline Prasinophytes & & & & & & 0.068 & 0.046 & & & & & & 0.002 & 0.368 & \\
\hline Cyanophytes & & & & & & & & & & & & 0.220 & & & \\
\hline Prochlorophytes & & & & & & & & & & & & 0.068 & & & 0.466 \\
\hline
\end{tabular}

\subsubsection{Phytoplankton Community Structure}

Highest total phytoplankton abundances occurred during spring tides, with a trend to decrease towards the inner

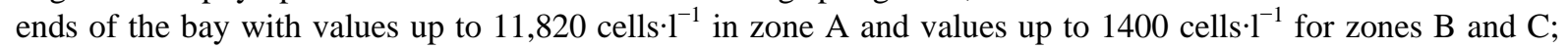
within each of the zones total abundance shows a patchy distribution (Figure 3(a)). Microscopic observations indicate that dinoflagellates were the most abundant group in the three zones, followed by diatoms and Cyanophytes (Figures 3(b)-(d)). Cyanophytes were observed in most of the stations within the bay from station 6 inward during the three tidal conditions. Prasinophytes were observed at stations 12 and 19 during neap tides, at stations 3 and 19 during the transition, and only in station 6 during spring tides. Raphidophytes were only found at station 22 during neap tides (Figure 3(b)). 

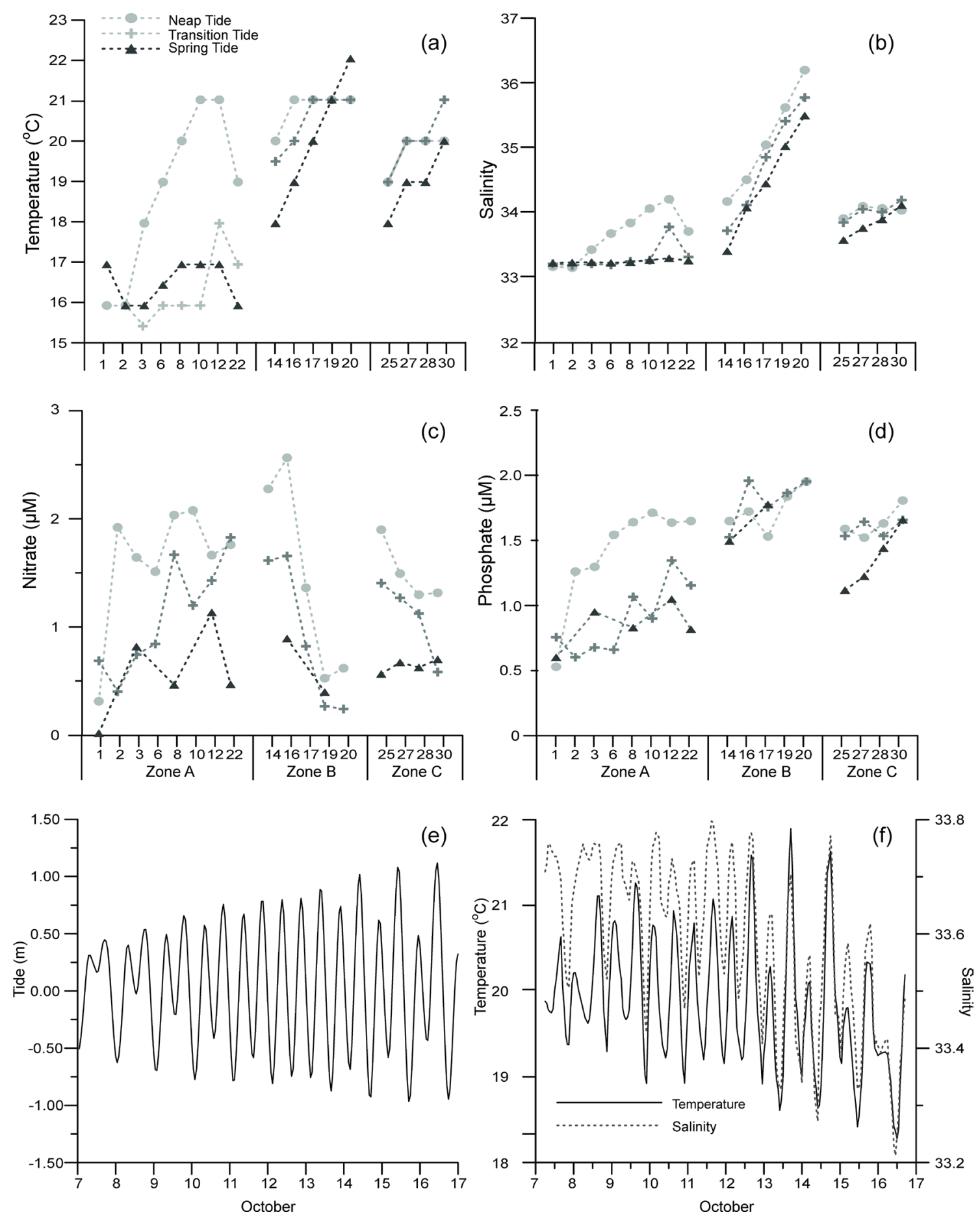

Figure 2. Surface temperature (a), salinity (b); nitrate (c) and phosphate (d) at the three sampling zones, during neap, transition and spring tides. Tide amplitude (e) and surface temperature and salinity (f) at the fixed station.

The number of genera identified within each group were: 24 diatoms, 16 dinoflagellates, four Cyanophytes, two Prasinophytes and one Raphidophyte (Table 2). Among the dinoflagellates, the genus Ceratium was the most abundant in the three zones, with concentrations up to $9320 \mathrm{cel} \cdot \mathrm{l}^{-1}$ in zone A, $1080 \mathrm{cel} \cdot \mathrm{l}^{-1}$ in zone B and $1040 \mathrm{cel} \cdot \mathrm{l}^{-1}$ in zone C (Table 2). The next most abundant genera were as follows: Scrippsiella $\left(2540 \mathrm{cel} \cdot \mathrm{l}^{-1}\right.$ ) and Prorocentrum $\left(1920 \mathrm{cel} \cdot l^{-1}\right)$ in zone A; Scrippsiella $\left(660 \mathrm{cel} \cdot{ }^{-1}\right)$ and Prorocentrum $\left(340 \mathrm{cel} \cdot l^{-1}\right)$ and Dinophysis 

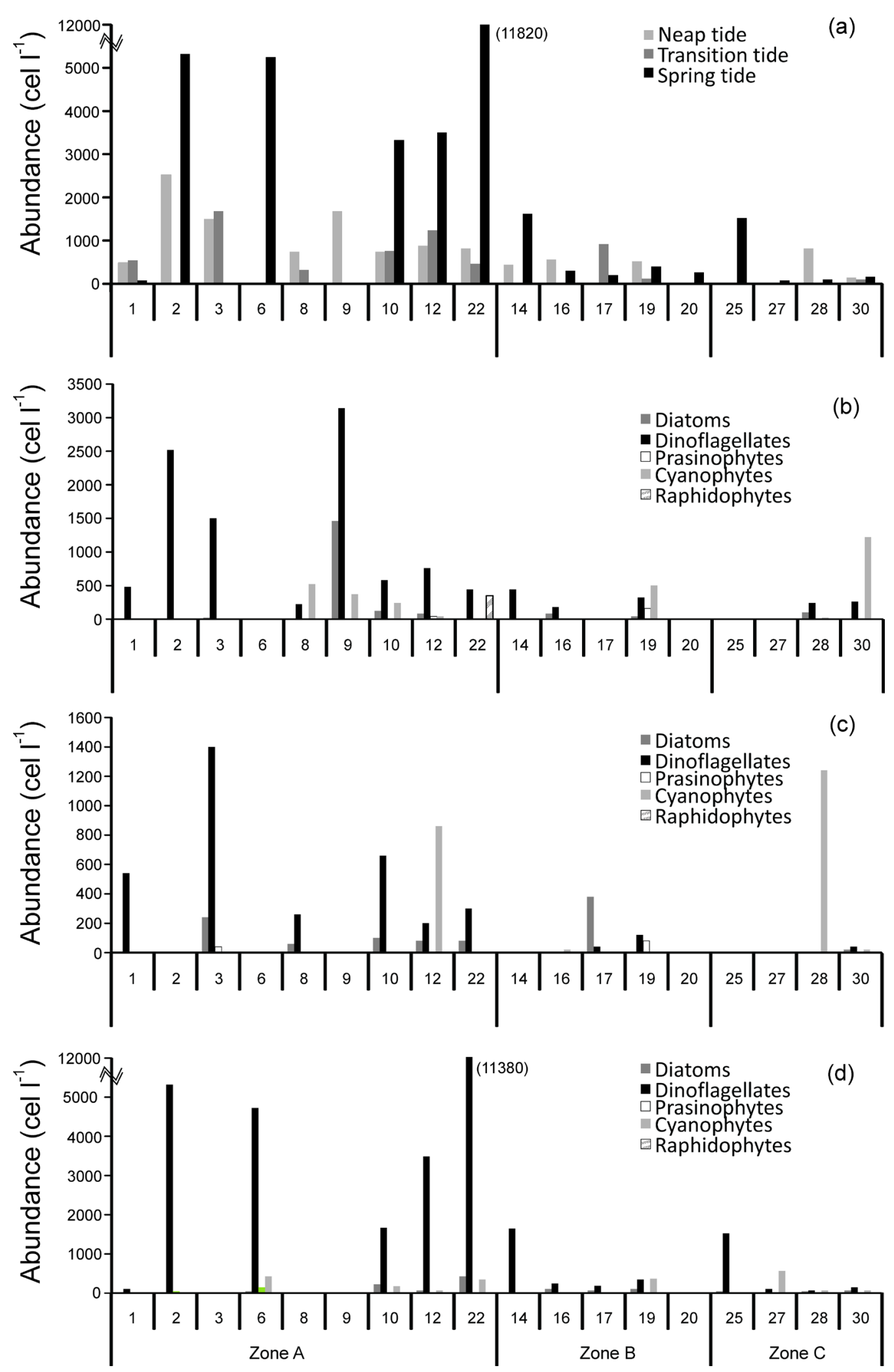

Figure 3. Phytoplankton abundance estimated by inverted microscope: (a) average of total phytoplankton $\left(\mathrm{cel} \cdot \cdot^{-1}\right)$ at neap, transition and spring tide for each zone. Average of phytoplankton genera abundance $\left(\right.$ cel $\left.\cdot l^{-1}\right)$ of groups observed by microscope at each zone during (b) neap, (c) transition and (d) spring tide. 
Table 2. Average phytoplankton genus abundance $\left(\mathrm{cel} \cdot \mathrm{l}^{-1}\right)$ estimated by microscope at zones A, B and C, and at time series station (TS) during $\mathrm{N}=$ neap, $\mathrm{T}$ = transition and $\mathrm{S}=$ spring tide. Diato (Diatoms); Dino (Dinoflagellates); Prasi (Prasinophytes); Cyano (Cyanophytes); Raphi (Raphidophytes).

\begin{tabular}{|c|c|c|c|c|c|c|c|c|c|c|c|c|c|}
\hline & \multirow{2}{*}{ Genus } & \multicolumn{3}{|c|}{ Zone A } & \multicolumn{3}{|c|}{ Zone B } & \multicolumn{3}{|c|}{ Zone C } & \multicolumn{3}{|c|}{ TS } \\
\hline & & $\mathrm{N}$ & $\mathrm{T}$ & S & $\mathrm{N}$ & $\mathrm{T}$ & S & $\mathrm{N}$ & $\mathrm{T}$ & S & $\mathrm{N}$ & $\mathrm{T}$ & S \\
\hline \multirow[t]{24}{*}{ Diato } & Achnanthes & & 80 & & & & & & & & & & \\
\hline & Campylodiscus & & 20 & & & & & & & & & & \\
\hline & Climacosphenia & 20 & & & & & & & & & & & 20 \\
\hline & Cocconeis & 360 & 120 & & & & & 40 & 40 & & 120 & 260 & 240 \\
\hline & Coscinodiscus & & 80 & & & & & & & & & & \\
\hline & Cyclotella & & 20 & & & & & & & & 40 & 20 & \\
\hline & Diploneis & & 40 & 40 & & & & & & & 120 & 40 & 20 \\
\hline & Dytilum & 20 & & & & & & & & & & & \\
\hline & Ephemera & 80 & 40 & & 40 & & & 20 & & & & 40 & 60 \\
\hline & Fragilaria & 280 & & & & & & & & & 340 & 480 & \\
\hline & Gyrosigma & 60 & & & & 40 & & 20 & & & & & 40 \\
\hline & Guinardia & 40 & & & & & & & & & & 100 & \\
\hline & Licmophora & 120 & & & & & & & & & & & \\
\hline & Manguinea & & & & & & & & & & & 40 & 40 \\
\hline & Mastogloia & 40 & 20 & 40 & & & & & & & & & \\
\hline & Navicula & 120 & 160 & 40 & 60 & 40 & 120 & 20 & 20 & & 620 & 860 & 440 \\
\hline & Nitszchia & 120 & & & & 100 & & & & & 2160 & 3220 & 320 \\
\hline & Odontella & & & & & & & & & & 40 & & \\
\hline & Pleurosigma & 80 & 20 & & & 20 & & & & & & 80 & \\
\hline & Pseudo-nitzschia & & & 500 & & 280 & & & & & 60 & & \\
\hline & Rhizosolenia & 320 & 20 & & & 400 & & 40 & & & & & 20 \\
\hline & Surirella & & & & & & & & & & 20 & & \\
\hline & Thalassionema & & & & & & & & & & & & 20 \\
\hline & Toxarium & & 80 & & & & & 40 & 40 & & 240 & 240 & 40 \\
\hline \multirow[t]{9}{*}{ Dino } & Ceratium & 220 & 220 & 9320 & & & 80 & & & 1040 & 40 & 20 & 2480 \\
\hline & Dinophysis & 180 & 80 & 1480 & & & 240 & & & 120 & 80 & 20 & 580 \\
\hline & Erythropsidinium & 40 & & 360 & & & & & & & & & \\
\hline & Gonyaulax & 280 & & 360 & 100 & 40 & 40 & & 40 & & 80 & 80 & 140 \\
\hline & Gymnodinium & 80 & 80 & 120 & 40 & & & & & & & & \\
\hline & Heterocapsa & & & & & & & & & & 260 & 40 & 80 \\
\hline & Heterodinium & 480 & 800 & 440 & 20 & & & & 40 & 100 & 460 & 340 & 240 \\
\hline & Lingoludinium & 60 & 40 & 120 & & & 60 & & 40 & & & 100 & 100 \\
\hline & Oxytoxum & 240 & 180 & 260 & 20 & & & & & & 40 & & \\
\hline
\end{tabular}




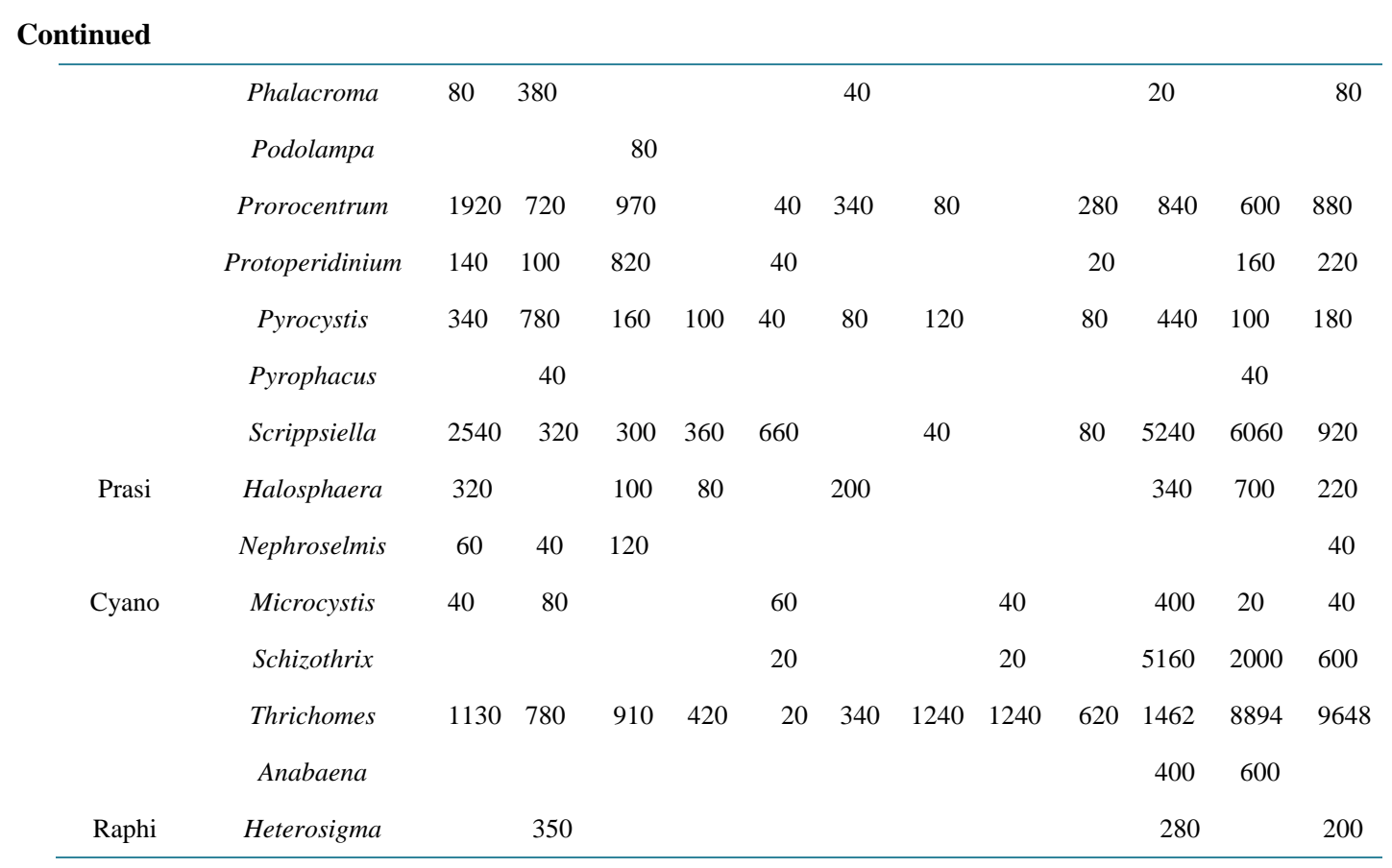

$\left(240 \mathrm{cel} \cdot \mathrm{l}^{-1}\right)$ in zone B; and Prorocentrum $\left(280 \mathrm{cel} \cdot \mathrm{l}^{-1}\right)$, Pyrocystis $\left(120 \mathrm{cel} \cdot \mathrm{l}^{-1}\right)$ and Dinophysis $\left(120 \mathrm{cel} \cdot \cdot^{-1}\right)$ in zone C (Table 2). Among the diatoms, the most abundant genera were Pseudo-nitzschia (500 cel. $\mathrm{l}^{-1}$ ), Rhizosolenia $\left(400 \mathrm{cel} \cdot \mathrm{l}^{-1}\right)$, Cocconeis $\left(360 \mathrm{cel} \cdot \mathrm{l}^{-1}\right)$ and Fragilaria $\left(280 \mathrm{cel} \cdot \mathrm{l}^{-1}\right)$. Pseudo-nitzschia, Fragilaria and Cocconeis in zone A; Rhizosolenia (400 cel-1 $\left.l^{-1}\right)$ and Pseudo-nitzschia $\left(280 \mathrm{cel} \cdot \mathrm{l}^{-1}\right)$ in zone B; and Cocconeis, Rhizosolenia and Toxarium with $\left(40 \mathrm{cel} \cdot \mathrm{l}^{-1}\right)$ in zone C (Table 2). Within cyanobacteria heterocystous trichomes were particularly abundant with 1130,420 and $1240 \mathrm{cel} \cdot 1^{-1}$ in zone A, B and C respectively (Table 2).

\subsubsection{HPLC Pigments}

In general, higher concentrations of TChla occurred in zone A and B during neap and transition tides, with concentrations between 1.0 and $4.4 \mu \mathrm{g} \cdot l^{-1}$. Zone C showed the smallest interval (1.5 to $2.5 \mu \mathrm{g} \cdot l^{-1}$ ) of TChla concentration throughout the sampling period. TChla in the lagoon decreased toward the inner ends (Figure 4(a)). Accessory pigments with the highest concentration in the spatial sampling were fucoxanthin, chlorophyll $b$ and alloxanthin. The concentration of fucoxanthin and chlorophyll $b$ showed the same trend as TChla, decreasing toward the lagoon interior, except for fucoxanthin in station 20, where it reached a concentration of $0.7 \mu \mathrm{g} \cdot \mathrm{l}^{-1}$ (Figures 4(b) and (c)). Alloxanthin presented an opposite trend, increasing toward the interior with maximum concentrations between 0.3 and $0.5 \mu \mathrm{g} \cdot \mathrm{l}^{-1}$, observed during neap tides in most of the stations of the three zones (Figure 4(d)). Peridinin, 19'-hexanoyloxyfucoxantina, prasinoxanthin, zeaxanthin and divinyl Chlrorophyll $a$, were present in low concentrations and had a trend to decrease toward the lagoon interior (Figure 4(e), (f), (h), (I), (j)). However, the highest peridinin concentrations during spring tides were found in the inner part of zone A $\left(0.21 \mu \mathrm{g} \cdot \mathrm{l}^{-1}\right)$ and zone $\mathrm{C}\left(0.18 \mu \mathrm{g} \cdot \mathrm{l}^{-1}\right)$. 19'-Hexanoyloxyfucoxanthin and prasinoxanthin concentrations were higher in zone A during the three tidal conditions (Figure 4(f)). Zeaxanthin and divinyl Chlrorophyll $a$ were higher during the transition tide in zone $\mathrm{A}$, ranging from 0.04 to $0.09 \mu \mathrm{g} \cdot \mathrm{l}^{-1}$ for zeaxanthin, and from $0.07 \mu \mathrm{g} \cdot \mathrm{l}^{-1}$ to undetectable values for divinyl Chlrorophyll $a$ (Figure 4(j)). Pheophytin $a$ had a trend to increase toward the interior of the lagoon, with values up to $0.09,0.14$ and $0.24 \mu \mathrm{g} \cdot \mathrm{l}^{-1}$ in zones $\mathrm{A}, \mathrm{B}$ and $\mathrm{C}$, respectively (Figure $4(\mathrm{~g}))$.

\subsubsection{Phytoplankton Groups Estimated by CHEMTAX}

The contribution of phytoplankton groups to the TChla varied under different tidal conditions. Cryptophytes, diatoms and Prasinophytes had a large contribution during most of the study (Figures 5(a)-(c)). Cryptophytes decreased from neap to spring tides, and increased toward the ends of the lagoon. Diatoms, showed a decreasing contribution toward spring tides only in zone A, while, there were no clear trend spatial distribution except for 

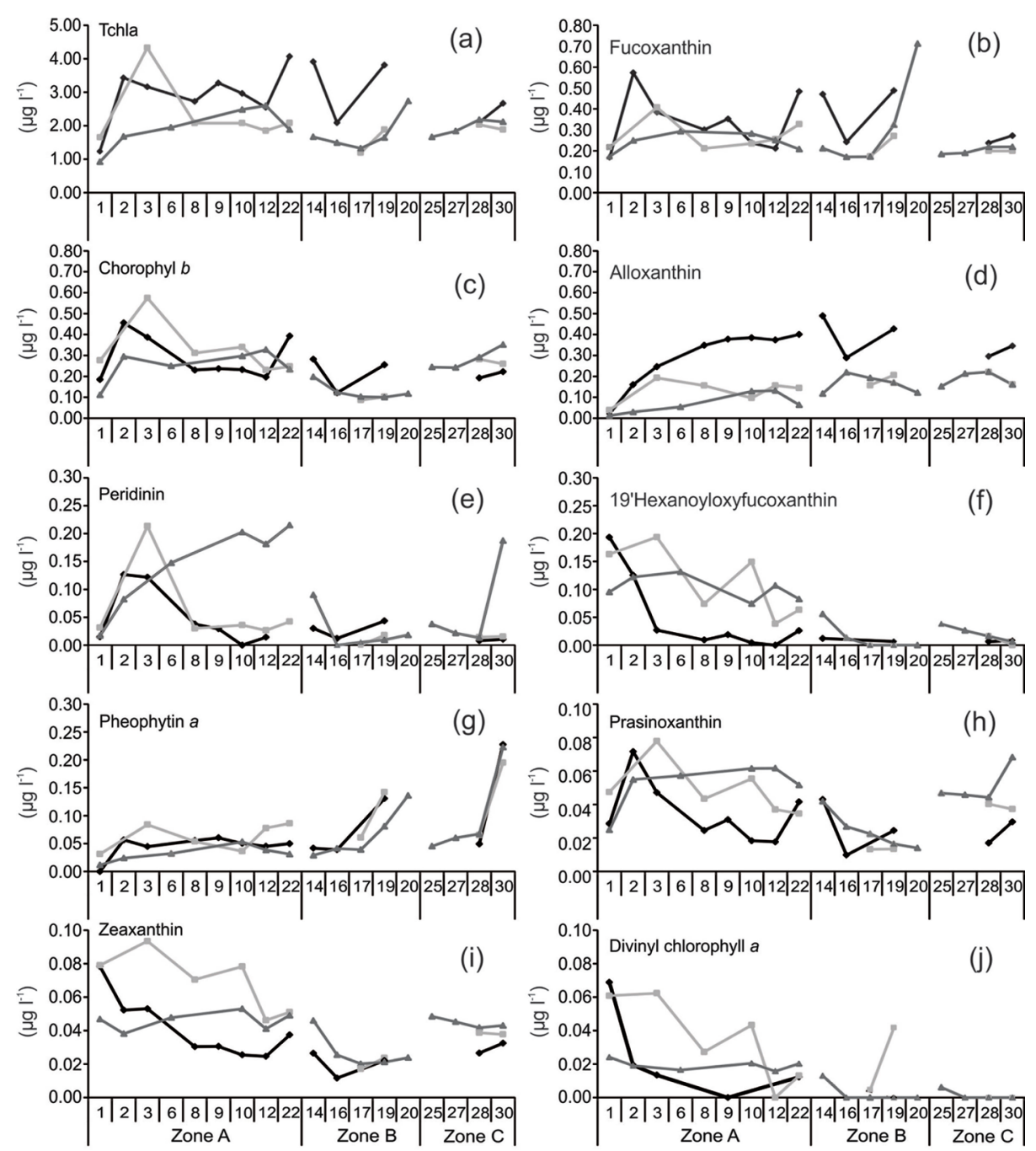

$\rightarrow$ Neap tide $(6-8$ oct)

- Transition tide(11-12 oct) $\quad-$ Spring tide (14-15 oct)

Figure 4. Pigment concentration $\left(\mu \mathrm{g} \cdot \mathrm{l}^{-1}\right.$ ) at the three zones: (a) TChla; (b) fucoxanthin; (c) chlorophyll $b$; (d) alloxanthin; (e) peridinin; (f) 19'-hexanoloxyfucoxanthin; (g) pheophytin $a$; (h) prasinoxanthin; (i) zeaxanthin and (j) divinyl chlorophyll $a$, during neap, transition and spring tides. Legend is indicated at the bottom.

an increase in zone B during transition and spring tides. Prasinophytes showed an increase during transition and spring tides, and a spatial trend to decrease toward the end of zone B (Figures 5(a)-(c)). The contribution of dinoflagellates and Haptophytes to TChla increased from neap to spring tides and decreased from the mouth to the ends of the lagoon. The contribution of Chlorophytes to TChla was the lowest during spring tides in the three zones, while Cyanophytes were the lowest during neap tide; none of these groups showed a clear spatial trend. The contribution of Prochlorophytes was low and sporadic during neap tides and showed a slight increase during transition and spring tides; the presence of this group was most noticeable in zone A (Figures 5(a)-(c)).

\subsubsection{Statistical Analysis}

Results of a one-way analysis of variance are shown in Table 3. Temperature was not significantly different between zones during neap tide, but differences were observed during transition and spring tides. Salinity was different between zones and under different tidal conditions. Nitrate concentration was different between stations only during neap tide, while phosphate was different between stations only during the transition of tide (Table 3(a)). Phytoplankton groups estimated by CHEMTAX showed significant differences between zone A 

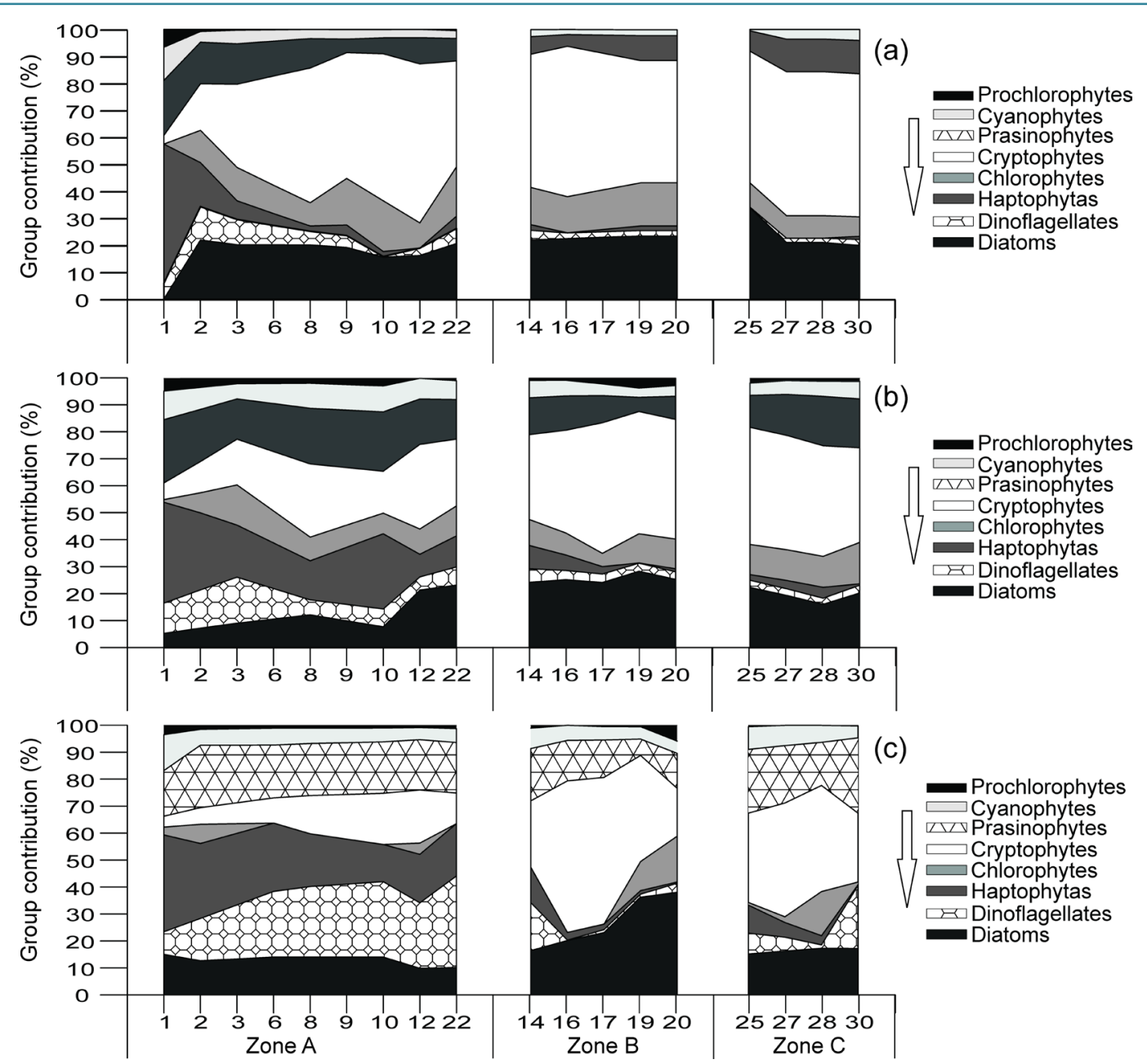

Figure 5. Percentage contribution of phytoplankton groups to TChla estimated by CHEMTAX at each zones and each tidal condition: (a) neap; (b) transition and (c) spring tide. The arrow indicates that the legend was organized in the same order as the graph, from top to bottom.

and zones B and C under the three tidal conditions, except for diatoms and Cryptophytes in neap tides (Table 3(a)). Chlorophytes, Haptophytes and Prochlorophytes had significant differences between zones and between tidal conditions, except for Haptophytes and Prochlorophytes between zone B and C during spring tide (Table 3(a)).

The abundance of all phytoplankton groups showed significant differences between neap and spring tides in zone A (Table 3(b)). Only Cryptophytes and Chlorophytes in zone C and Prasinophytes and Prochlorophytes in zone B showed significant differences between neap and spring tides (Table 3(b)).

\subsection{Time Series}

\subsubsection{Hydrographic Conditions}

Sampling in the time series station was initiated during neap tide with an amplitude of $1.2 \mathrm{~m}$ ( -0.65 to $0.55 \mathrm{~m}$ interval referred to mean sea level) and ended in spring tide with an amplitude of $2.05 \mathrm{~m}$ ( -0.95 to $1.1 \mathrm{~m}$ ) (Figure 2(e)). The temperature at the beginning of the time series ranged from $19.4^{\circ} \mathrm{C}$ to $20.6^{\circ} \mathrm{C}$, reached a maximum daily range $\left(18.5^{\circ} \mathrm{C}\right.$ to $21.9^{\circ} \mathrm{C}$ ) on October 13 (Figure 2(f)) and showed a decreasing trend in the daily maximum and minimum values at the end of the time series during spring tides. As in the case of temperature, maximum and minimum salinity values were higher during neap tides and decreased toward the end of the series during spring tides (Figure 2(d)). Samples were not collected for nutrient analysis at the fixed station, however, nitrate and phosphate concentrations at station 27 (near station 26) collected during the spatial sampling, ranged 
Table 3. One way analysis of variance: a) between zones for each tidal condition; b) between tidal condition for each zone; and c) between tidal condition at the fixed station. $\mathrm{A}=$ zone $\mathrm{A}, \mathrm{B}=$ zone $\mathrm{B}, \mathrm{C}=$ zone $\mathrm{C} ; \mathrm{N}=$ neap, $\mathrm{T}=\mathrm{Transi}-$ tion, $\mathrm{S}=$ spring; $\mathrm{S}=$ Significative, NS = Non Significative, $(\alpha=0.05)$.

\begin{tabular}{|c|c|c|c|c|c|c|c|c|c|}
\hline \multirow{2}{*}{ a) } & \multicolumn{3}{|c|}{ Neap tide } & \multicolumn{3}{|c|}{ Transition tide } & \multicolumn{3}{|c|}{ Spring tide } \\
\hline & $A$ vs $B$ & A vs $C$ & B vs $C$ & A vs $B$ & A vs C & B vs $C$ & A vs B & A vs $C$ & B vs $\mathrm{C}$ \\
\hline Temperature & NS & NS & NS & S & S & S & S & S & S \\
\hline Salinity & S & S & S & S & S & S & S & S & S \\
\hline Nitrate & S & S & S & NS & NS & NS & NS & NS & NS \\
\hline Phosphates & NS & NS & NS & S & S & S & NS & NS & NS \\
\hline Diatoms & NS & NS & NS & S & S & S & S & S & NS \\
\hline Dinoflagellates & S & S & NS & S & S & NS & S & S & NS \\
\hline Haptophytes & S & S & S & S & S & S & S & S & NS \\
\hline Chlorophytes & S & S & S & S & S & S & S & S & S \\
\hline Cryptophytes & NS & NS & NS & S & S & S & S & S & S \\
\hline Prasinophytes & S & S & NS & S & S & S & S & S & S \\
\hline Cyanophytes & S & S & NS & S & S & S & S & S & S \\
\hline Prochlorophytes & S & S & S & S & S & S & S & S & NS \\
\hline TChla & NS & NS & NS & S & S & NS & NS & NS & NS \\
\hline \multirow{2}{*}{ b) } & \multicolumn{3}{|c|}{ Zone A } & \multicolumn{3}{|c|}{ Zone B } & \multicolumn{3}{|c|}{ Zone C } \\
\hline & $\mathrm{N}$ vs $\mathrm{T}$ & $\mathrm{N}$ vs $\mathrm{S}$ & T vs S & $\mathrm{N}$ vs $\mathrm{T}$ & $\mathrm{N}$ vs $\mathrm{S}$ & T vs S & $\mathrm{N}$ vs $\mathrm{T}$ & $\mathrm{N}$ vs $\mathrm{S}$ & T vs S \\
\hline Temperature & S & S & NS & S & S & S & NS & NS & NS \\
\hline Salinity & S & S & S & S & S & NS & NS & NS & NS \\
\hline Nitrate & S & NS & NS & NS & NS & NS & NS & NS & NS \\
\hline Phosphates & S & S & NS & NS & NS & NS & NS & NS & NS \\
\hline Diatoms & NS & S & S & NS & NS & NS & NS & NS & NS \\
\hline Dinoflagellates & NS & S & S & NS & NS & NS & NS & NS & NS \\
\hline Haptophytes & S & S & NS & S & NS & NS & NS & NS & NS \\
\hline Chlorophytes & NS & S & S & NS & NS & NS & NS & S & S \\
\hline Cryptophytes & $\mathrm{S}$ & S & $\mathrm{S}$ & NS & NS & S & S & S & NS \\
\hline Prasinophytes & $\mathrm{S}$ & S & NS & S & $\mathrm{S}$ & NS & NS & NS & NS \\
\hline Cyanophytes & $\mathrm{S}$ & $\mathrm{S}$ & $\mathrm{S}$ & S & NS & NS & NS & NS & NS \\
\hline Prochlorophytes & S & S & NS & NS & S & S & NS & NS & NS \\
\hline TChla & NS & S & S & NS & NS & NS & NS & NS & NS \\
\hline \multirow{2}{*}{ c) } & \multicolumn{9}{|c|}{ Time Series Station } \\
\hline & $\mathrm{N}$ vs $\mathrm{T}$ & $\mathrm{N}$ vs $\mathrm{S}$ & T vs S & & & & $\mathrm{N}$ vs $\mathrm{T}$ & $\mathrm{N}$ vs $\mathrm{S}$ & T vs $\mathrm{S}$ \\
\hline Temperature & NS & NS & NS & & Chlorophyt & & S & $\mathrm{S}$ & NS \\
\hline Salinity & NS & S & $\mathrm{S}$ & & Cryptophyt & & S & S & S \\
\hline Diatoms & NS & NS & NS & & Prasinophyt & & S & S & $\mathrm{S}$ \\
\hline Dinoflagellates & NS & NS & NS & & Cyanophyte & & S & S & NS \\
\hline Haptophytes & NS & NS & NS & & rochlorophy & & NS & NS & NS \\
\hline TChla & S & S & NS & & & & & & \\
\hline
\end{tabular}


from 0.5 to $1.5 \mu \mathrm{M}$ (Figure 2(c)) and 1.1 to $1.5 \mu \mathrm{M}$ (Figure 2(d)) respectively.

\subsubsection{Phytoplankton Community Structure}

In the time series, total phytoplankton abundance showed high variability, with values from $<100$ up to 9600 cel $\cdot l^{-1}$. The highest phytoplankton abundances were associated with the presence of Cyanophytes (unidentified non heterocystous filamentous cyanobacteria) (Figures 6(a) and (c)). Dinoflagellates were abundant during the
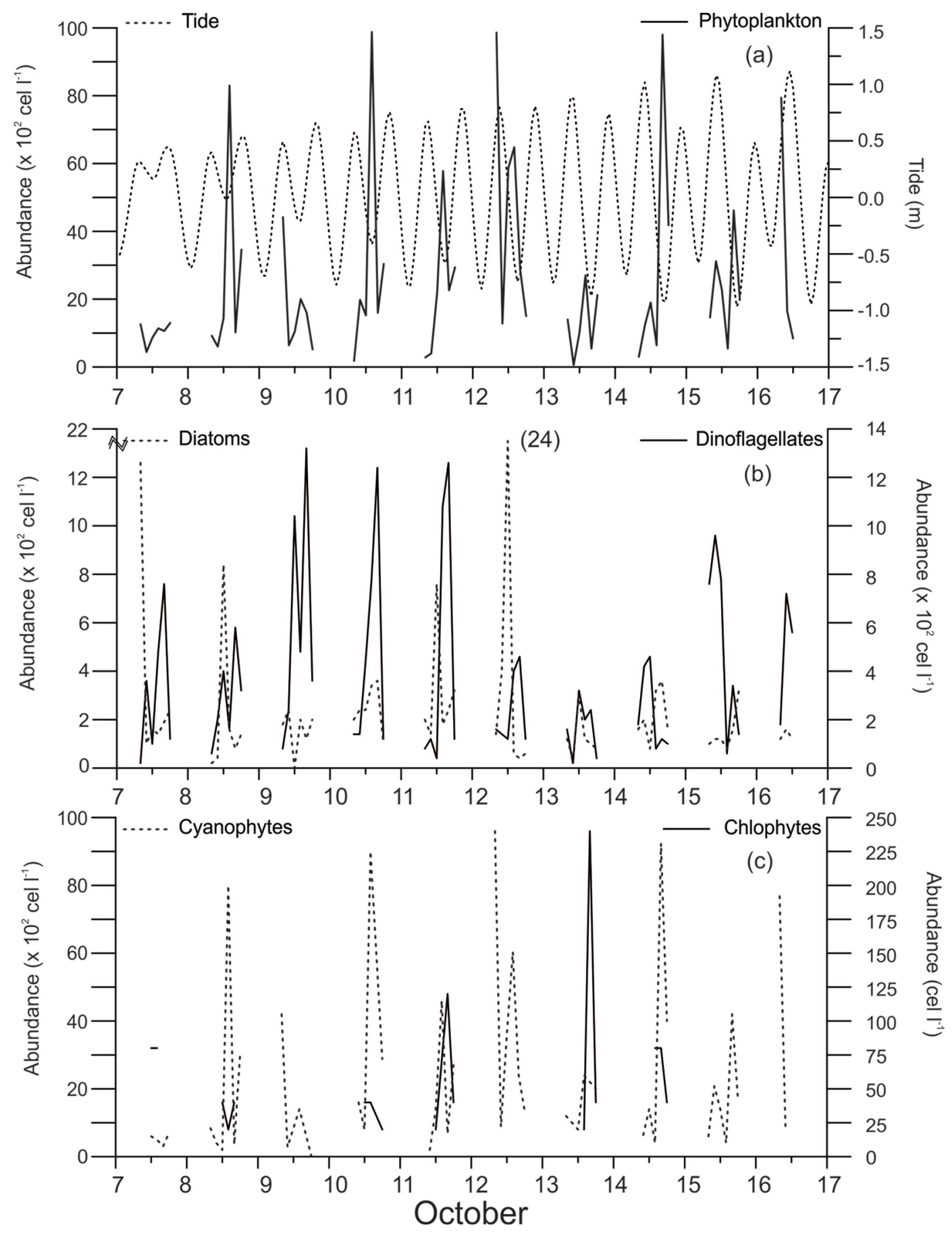

Figure 6. (a) Total phytoplankton abundance $\left(\mathrm{cel} \cdot \mathrm{l}^{-1}\right)$ estimated by inverted microscope and tide level (m) at the fixed station. Group abundance $\left(\mathrm{cel} \cdot \mathrm{l}^{-1}\right)$ at the fixed station: (b) Diatoms and dinoflagellates; (c) Cyanophytes and Chlorophytes. 
first five days of sampling and reached $1320 \mathrm{cel} \cdot \mathrm{l}^{-1}$ (Figure 6(b)); the most abundant genera were Scrippsiella $\left(6060 \mathrm{cel} \cdot \cdot^{-1}\right.$ ) and Ceratium (2480 cel $\cdot \cdot^{-1}$ ) (Table 2). Diatoms showed little variation except for some peaks during the ebbing tides. However, its highest abundance of $2140 \mathrm{cel} \cdot \mathrm{l}^{-1}$ occurred during the transition to spring tide (Table 2, Figure 6(b)). Among the diatoms, Nitzschia, Navicula and Fragilaria genera were the most abundant (Table 2). The genera Nephroselmis (Prasinophytes) showed little variation during the time series with averages of $40 \mathrm{cel} \cdot \mathrm{l}^{-1}$ during the spring tide (Table 2). For Raphidophytes only one genus (Heterosigma) was observed but it was scarce and observed only at the beginning and end of sampling (Table 2).

\subsubsection{Pigments}

TChla presented a generally decreasing trend throughout the time series, however, peaks of $3.5 \mu \mathrm{g} \mathrm{l}^{-1}$ were observed during spring tides (Figure 7(a)). Fucoxanthin showed an increasing trend toward spring tides, reaching a maximum of $0.67 \mu \mathrm{g} \cdot \mathrm{l}^{-1}$, meanwhile alloxanthin showed an opposite trend with a maximum of $0.83 \mu \mathrm{g} \cdot \mathrm{l}^{-1}$ in neap tide (Figure 7(b)). Chlorophyll $b$ decreased toward spring tides, from values of 0.38 to $0.30 \mu \mathrm{g} \cdot \mathrm{l}^{-1}$, excluding one value of $0.70 \mu \mathrm{g} \cdot 1^{-1}$ occurring in spring tides (Figure 7(b)). Peridinin and 19'-hexanoyloxyfucox-anthin showed low concentrations with small variation during the first sampling days, both pigments increased from mean values of 0.015 up to 0.06 and $0.05 \mu \mathrm{g} \cdot \mathrm{l}^{-1}$, respectively, toward the end of sampling (Figure 7(c)). Divinyl chlorophyll $a$ was detected sporadically in the time series with a maximum concentration of $0.017 \mu \mathrm{g} \cdot \mathrm{l}^{-1}$ (Figure 7 (c)). Prasinoxanthin and zexanthin showed values up to $0.10 \mu \mathrm{g} \cdot \mathrm{l}^{-1}$ and $0.08 \mu \mathrm{g} \cdot \mathrm{l}^{-1}$, respectively, both showed a trend to increase during spring tides. Phaeophytin $a$ showed a trend to increase during spring tides $\left(0.04\right.$ to $\left.0.13 \mu \mathrm{g} \cdot \mathrm{l}^{-1}\right)$ with higher values during the ebbing tide (Figure 7(d)), and higher variability at the end of the series.

\subsubsection{Phytoplankton Groups Estimated by CHEMTAX}

Cryptophytes had the largest contribution to TChla, up to $47 \%$ throughout the series, and a trend to decrease during spring tides (Figure 8(b)). Diatoms showed a relatively constant contribution throughout the series with approximately $20 \%$. Chlorophytes had a larger contribution at the beginning of the sampling ( 20\%), and tended to decrease during spring tides ( 15\%). Prasinophytes had a very small contribution (10\%) at the beginning of the series reaching $\sim 30 \%$ toward the end of the series. Dinoflagellates and Haptophytes showed a small variation in the contribution to TChla along the time series with 3\% to 8\%. Cyanophytes showed little variation throughout the series, with an increasing trend during spring tides. Prochlorophytes occurred sporadically, contributing a maximum of $1 \%$ to TChla.

\subsubsection{Statistical Analysis}

The analysis of variance showed significant differences for Chlorophytes, Cyanophytes, Cryptophytes and Prasinophyes among the three tidal conditions, except for Chlorophytes and Cyanophytes when comparing transition and spring tides. In the time series station, the abundance of diatoms, dinoflagellates and Haptophytes was not statistically different among tidal conditions (Table 3(c)).

\section{Discussion}

\subsection{Hydrographic Conditions}

In our study, temperature and salinity values increased from zone A toward the inner shallow areas (Figures 2(a) and (b)) which have higher residence times [17] [18]. This spatial distribution pattern for temperature and salinity in SQB has been reported in previous studies [3] [5] which took place during spring-summer, the upwelling season [27]. However, in contrast with those studies, during our study oceanic temperatures were higher and salinities were lower because upwelling was weak or absent in the adjacent ocean. Nitrate concentrations were much lower than those reported for May-June of the same year, when concentrations up to $12.3 \mu \mathrm{M}$ were observed in zone A [5] at the fixed station during upwelling events. Temperature in this station tended to decrease during spring tides (Figure 2(f)) due to an increase in the intrusion of water from the adjacent ocean during flood tide [3] [16]. The highest temperatures during the ebbing tides indicate that water comes from the innermost shallow portions of the lagoon where water has the longest residence time (Figure 2(b)).

\subsection{Phytoplankton Abundance and Community Structure}

The average phytoplankton abundance counted by microscopy (Figure 3) in our study was two times lower than 

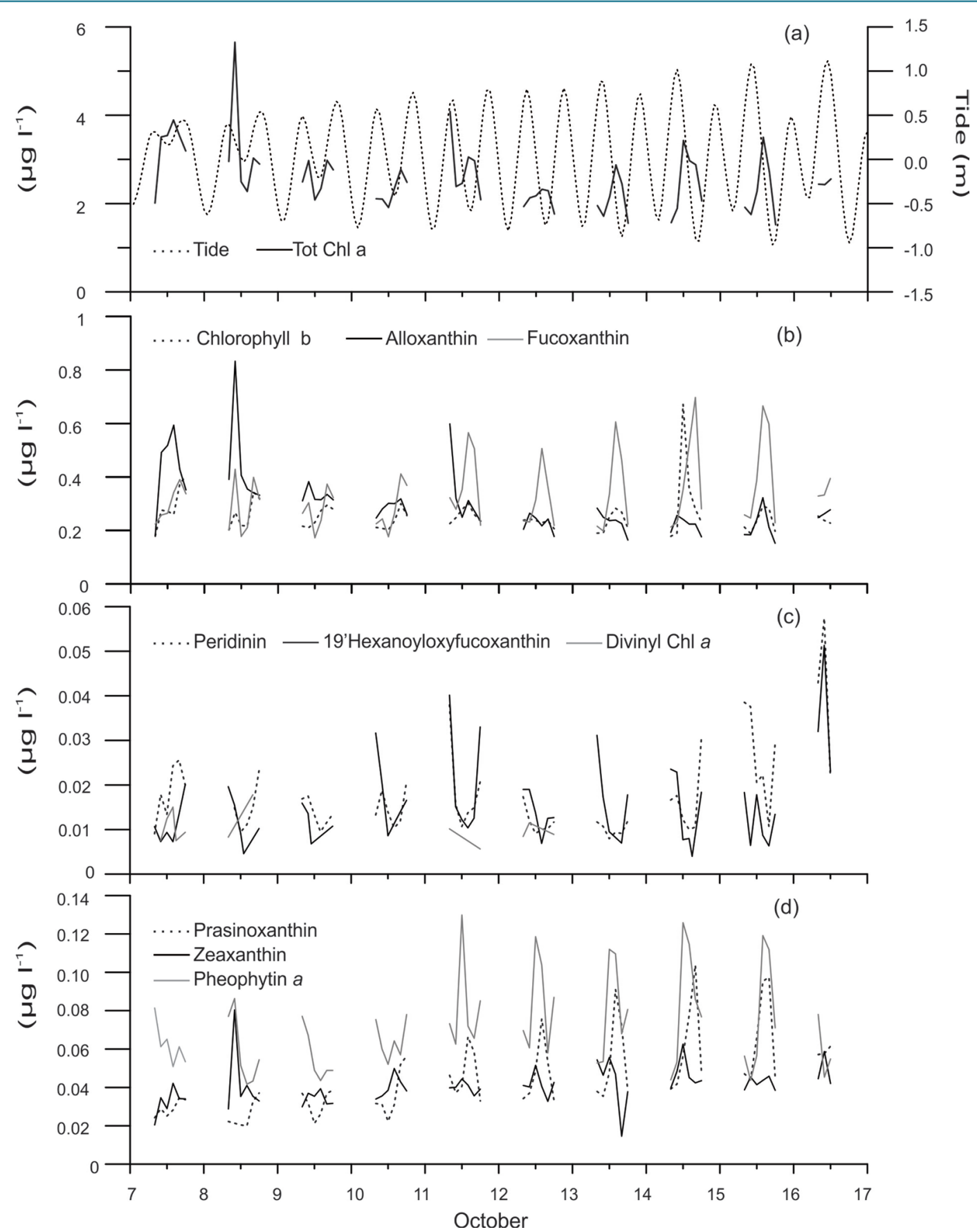

Figure 7. (a) Total chlorophyll $a$ concentration $\left(\mu \mathrm{g} \cdot l^{-1}\right)$ and tide level (m) at the fixed station; (b) chlorophyll $b$, alloxanthin and fucoxanthin; (c) peridinin, 19'-hexanoyloxyfucoxanthin and divinyl chlorophyll $a$; (d) prasinioxanthin, zexanthin and pheophytin $a$.

abundances observed in the upwelling season (May-June 2004) by Moreno-Miranda [5]. Lower phytoplankton abundances in October can be associated to seasonal changes in the oceanographic conditions in the adjacent ocean. In contrast with spring-summer when the California Current is closer to the Baja California coast, during autumn the California Current weakens and separates from the coast, allowing subtropical water to reach the coastal area adjacent to SQB [28]. We can define this condition as oligotrophic, because subtropical water shows relatively high temperature and low dissolved inorganic nitrogen, leading to relatively low chlorophyll concentrations as reported by Durazo et al. [28] and Gaxiola-Castro et al. [29]. Several studies show that phy- 


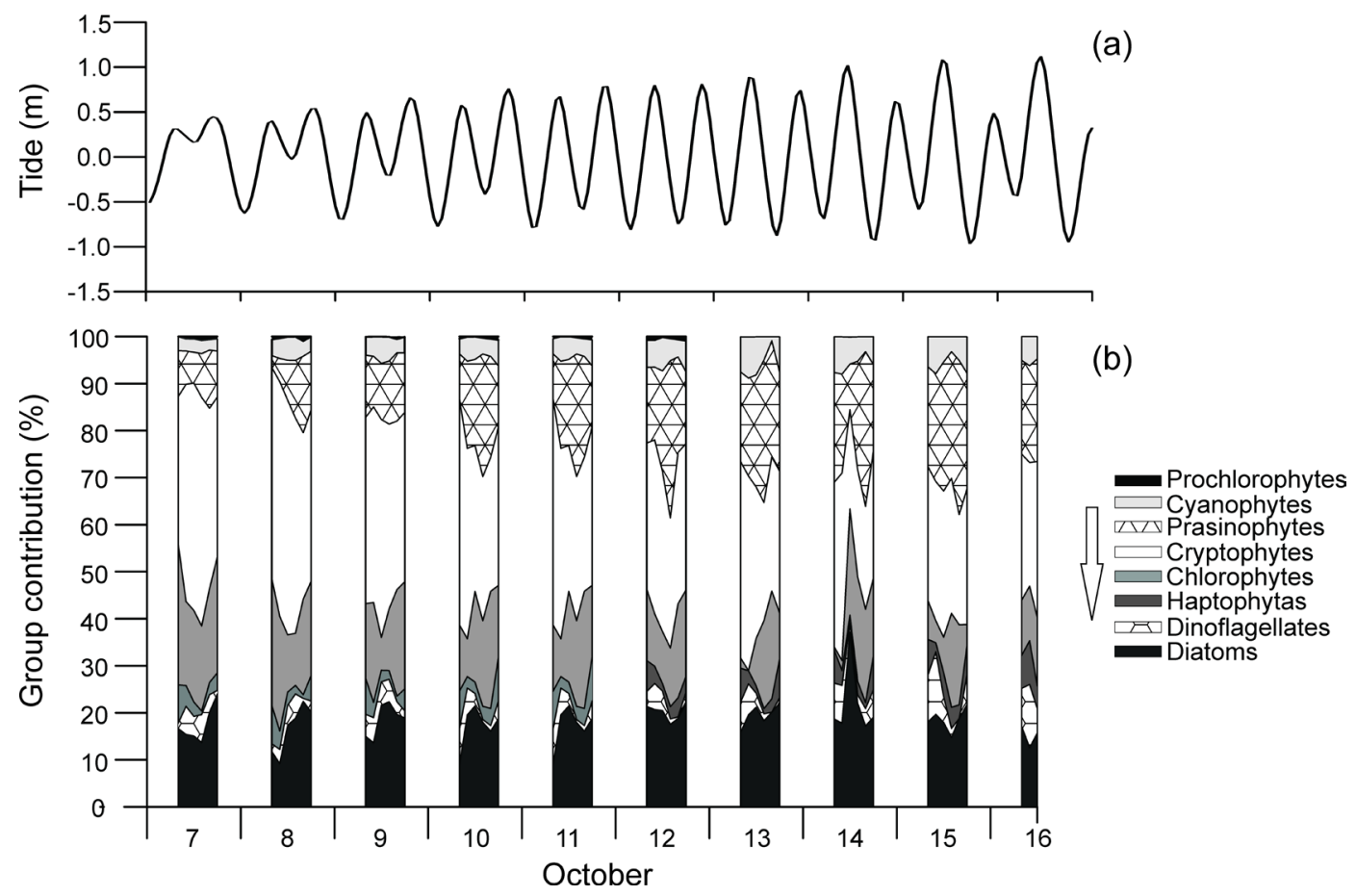

Figure 8. (a) Tidal amplitude (m); (b) percentage contribution of phytoplankton groups to TChla estimated by CHEMTAX at the time series stations. The arrow indicates that the legend was organized in the same order as the graph, from top to bottom. Blank spaces between bars are night hours when no data was taken.

toplankton community structure is influenced by temperature [30]-[32]. Among microplankton, diatoms generally dominate at low temperatures, flagellates in warm waters, and picoplankton is more abundant at high temperatures [30]. SQB is no exception; during our study, observations with microscope show that dinoflagellates, diatoms and Cyanophytes were the most abundant phytoplankton groups in the lagoon, mainly in zone A. However, CHEMTAX results showed that Cryptophytes, a group difficult to observe with microscope, were dominant. Higher phytoplankton abundances in zone A were due to higher water exchange with the adjacent ocean as compared with zones B and C. Lower phytoplankton abundances in zones B and C, are likely explained by higher residence times [18], and low nitrate concentrations (Figure 2). In addition, these inner zones are shallower and have higher turbidities caused by sediment re-suspension and consequently a reduction in light penetration [3] [23].

Zone C presented the lowest phytoplankton abundances and diversity. In this zone, Cyanophytes outnumbered other groups observed in the microscope, mainly during ebbing tides (Figure 6(c)). A commercial culture of Japanese oyster Crassostrea gigas is established in this area, which results in an increase in the organic matter content in bottom sediments [33] therefore intertidal sediments may have the ideal conditions to promote the growth of microbial mats with heterotrophic (non heterocystous filamentous) Cyanobacteria [34]. In addition, the low abundance of microphytoplankton in zone C may be also related to oyster cultures. A deficit of phytoplankton and chlorophyll a up to $44 \%$ has been observed in places with high water flow and high bivalve density [35], as oysters feed on cells larger than $1 \mu \mathrm{m}$, which can be retained by their gills [36].

Diatom abundances were lower in our study as compared to those observed in SQB for May-June of the same year [5]. During upwelling events diatoms tend to be dominant as they can bloom under high turbulence conditions [37]. However during our sampling diatom growth was limited by the lack of upwelling and the resulting low turbulence and low nitrate concentrations (Figures 3(c) and (d)). A decrease in the diatoms group toward the ends of the lagoon may be explained by an even stronger nitrogen limitation, as nitrate concentrations in this zones are low or undetectable (Figure 2(e)).

Our results show that Navicula and Nitzschia were the most abundant diatoms, these genera have also been reported as abundant during the upwelling conditions; in contrast, Cocconeis in our study was relatively scarce while it has also been reported has abundant during upwelling season [3]-[5]. The community of dinoflagellates 
in our study which had Ceratium, Scripsiella, Prorocentrum and Dinophysis as the most abundant genera, had a similar composition as that observed under upwelling conditions [4] [5], although abundances may vary between seasons.

Filamentous cyanobacteria were occasionally present in our study in high numbers (up to $9600 \mathrm{cell} \cdot \mathrm{l}^{-1}$; Figure 6(c)) coinciding with the ebbing tide. These high values probably resulted from the resuspension of $\mathrm{N}_{2}$-fixing cyanobacteria mats which are common in shallow intertidal mud flats of coastal ecosystems [34] [38].

In SQB, the abundance and the taxonomic composition of phytoplankton, at least to generic level, changes under different tidal conditions, in time scales of hours and days resulting in a patchy distribution. For example, for diatoms and dinoflagellates abundance changed in a matter of two hours from $<100$ to $>800 \mathrm{cell} \cdot \mathrm{l}^{-1}$ (Figure 6(b)). Phytoplankton patchiness associated with strong tidal dynamics has been described and is a common feature of tidally driven estuaries [39] [40].

\subsection{Pigments and CHEMTAX}

The highest contribution of peridinin to TChla was $20 \%$ in the area of the mouth, a contribution greater than that reported by Moreno-Miranda [5] in May-June of 2004. In the fixed station, the contribution of dinoflagellates to TChla was up to $8 \%$ and agrees with the peridinin concentration (Figure 8), however, this finding does not agree with abundances of dinoflagellates estimated by microscopic observations (Figure 6(b)). This lack of agreement between pigments and microscopic observations has been reported for others places [11] [41]-[43] and may be due to the presence of heterotrophic/mixotrophic dinoflagellates containing fucoxanthin, alloxanthin, 19'-hexanoyloxyfucoxanthin and chlorophyll $b$ [21] [43]. 19'-hexanoyloxyfucoxanthin is characteristic of Haptophytes and was abundant in zone A (Figure 4(f)). The presence of Haptophytes such as coccolithophores has been reported in oligotrophic waters off Baja California [44].

In our study, the phytoplankton contribution to TChla showed that Cryptophytes were the most abundant group, contributing up to $55 \%$ in the spatial sampling and 50\% in the time series station (Figures $\mathbf{5}$ and $\mathbf{8}$ ). These values are higher than those reported by Moreno-Miranda [5] during upwelling conditions when this group was also dominant. Cryptophytes grow under high dissolved organic matter concentrations and have the ability to tolerate low-nutrient conditions [45]. SQB is characterized by high dissolved organic carbon concentrations [15], and presents high abundance of seagrass (Zostera marina) and macroalgae (Ulva spp.) which consume dissolved inorganic nitrogen at high rates, reducing its availability in the water column within the lagoon even during the upwelling season [46]. Although the reasons why Cryptophytes thrive in SQB are unknown, given their high numbers they most play an important ecological and biogeochemical role that should be evaluated.

In general, the contribution of diatoms to TChla agrees with the fucoxanthin concentration, but it is frequently higher than the abundance estimated under the microscope. Higher contribution estimated by CHEMTAX may be because fucoxanthin is also present in other groups such as Prymnensiophytes, Chrysophytes and Haptophytes [47], which as small diatoms are difficult to observe under the microscope.

The contribution of Prasinophytes to TChla varied as the concentration of its specific pigment prasinoxanthin; however, the Prasinophyte abundance estimated by microscope does not agree with the CHEMTAX estimation, due to the difficulty of their observation with microscope. Millán-Núñez et al. [2] and Moreno-Miranda [4] reported up to $10 \%$ contribution of Prasinophytes, whereas we report up to $30 \%$ in spring tides with a decreasing trend from the mouth to the end of zone $\mathrm{B}$ and an increase toward the end of zone $\mathrm{C}$ (Figure 5). This difference between the inner arms can be explained as zone $C$ has a lower residence time thus higher connectivity with the adjacent ocean than zone B [18]. This pattern is also reflected with an increasing trend in spring tides in the fixed station.

Higher contributions of Chlorophytes were observed in Zone A, while at the fixed station they showed a trend to increase during spring tides, suggesting that chlorophyll $b$ is coming from Zone A. It is possible that an overestimation of Chlorophytes occurred because vascular plants also contain Chlorophyll $b$ [23]. Estuaries and coastal lagoons generally receive contributions of chlorophyll $b$ from vascular plant detritus, and gametes and spores of macroalgae [48]. Ulva spp. is present in SQB throughout the year and it is abundant in zone A where its production is likely regulated by the availability of nitrogen, and its biomass has a significant seasonal variation, being greater during June-July [46] [48]. Meanwhile, Zostera marina has its maximum biomass in September and October, when the production is usually regulated by irradiation and temperature [46] [49]. Thus, 
Chlorophyll $b$ in SQB can be partly attributed to the contribution of green macroalgae and seagrasses. The presence of Prasinophytes which also contain chlorophyll $b$ as a characteristic pigment may lead to overestimation of Chlorophytes by CHEMTAX [21].

In SQB the presence of Prochlorococcus indicates the occurrence of oceanic oligotrophic waters within the lagoon. Prochlorophytes in SQB were first reported for April 2001 [2], with a contribution up to $40 \%$ and a Divinyl Chlorophyll $a$ concentration of $0.19 \mathrm{mg} \cdot \mathrm{m}^{-3}$. However, during upwelling events in May-June of 2004, the concentration of Divinyl chlorophyll $a$ reported by Moreno-Miranda [5] was $0.05 \mu \mathrm{g} \cdot \mathrm{l}^{-1}$, with a contribution to TChla less than $1 \%$. In our study Prochlorophytes showed a maximum of $7 \%$, but occurred sporadically with a trend to decrease toward the lagoon interior (Figure 4(j)). In the fixed station Prochlorophytes had a sporadic occurrence reaching up to 1\% (Figure 8). The large variability in the contribution of Prochlorococcus in SQB probably reflects interannual oceanographic variability. Even though we regard our sampling condition as oligotrophic and should expect a large Prochlorococcus contribution, its contribution in April 2001 was noticeably higher. Between 2003 and 2006 the California Current had a larger volume of subarctic water as indicated by negative salinity anomalies off Baja California, while 2001 was within a period of positive anomalies [28]. This observation implies that in our study region during the autumn season there was less tropical water than during spring 2001.

In general, each phytoplankton group responds in a different manner to changes in hydrographic conditions. There are important differences in temperature, salinity and nutrient spatial distribution in the lagoon that determine the observed differences in the abundance of phytoplankton groups among zones during the same tidal condition (Table 3). Results of statistical analyses of the effect of tidal conditions on phytoplankton composition indicate that Zone A is strongly affected by tides, and that tidal effects are lessened at the inner zones are less. In the time series station changes in diatom and dinoflagellate abundances were non significant under different tidal conditions, but changes were significant for Chlorophytes, Cyanophytes, Cryptophytes and Prasinophytes, under contrasting tidal conditions. Differences in phytoplankton abundance between zones and between tidal conditions indicate that phytoplankton distribution is patchy in the lagoon.

\section{Conclusion}

The CHEMTAX analysis was successful for estimating biomass of dominant phytoplankton groups that are difficult to be observed by inverted microscope. Cryptophytes had the highest contribution to TChla in most stations of the lagoon. Although the reasons why Cryptophytes thrive in SQB are unknown, given their high abundance they must play an important ecological and biogeochemical role that should be evaluated. The contribution of most phytoplankton groups to TChla showed significant differences between zones at the same tidal conditions as a response to spatial gradients of the environmental conditions (temperature, salinity, nutrient concentrations, bathymetry, and residence times). Our results also show that tidal conditions determine the phytoplankton community structure particularly in the zone most influenced by oceanic conditions. Measurements at the fixed station allowed us to observe the patchiness in the phytoplankton distribution including noticeable changes in abundance in short time scales controlled by tidal currents.

\section{Acknowledgements}

The first author acknowledgements the National Council of Science and Technology (CONACyT) for support during graduate studies, as well as project D40144-F "Physical, geochemical and biological responses of San Quintín Bay to upwelling water pulses from the adjacent sea”. We also thank Dra. Elizabeth Orellana for her helps and support with phytoplankton identification.

\section{References}

[1] Álvarez-Borrego, S. and De Muñoz, S.N. (1979) Series de tiempo de fitoplancton en dos lagunas costeras de Baja California. Ciencias Marinas, 6, 1-19.

[2] Millán-Núñez, R., Álvarez-Borrego, S. and Nelson, D.M. (1982) Effects of Physical Phenomena on the Distribution of Nutrients and Phytoplankton Productivity in a Coastal Lagoon. Estuarine Coastal and Shelf Science, 15, 317-335. http://dx.doi.org/10.1016/0272-7714(82)90066-X

[3] Millán-Núñez, R., Millán-Núñez, E., Álvarez-Borrego, S., Trees, C. and Santamaría-del-Ángel, E. (2004)Variabilidad de la comunidad del fitoplancton en Bahía San Quintín estimada mediante el análisis de pigmentos. Ciencias Marinas, 
30, 35-43.

[4] Montes-Hugo, M.A. and Álvarez-Borrego, S. (2007) Impact of Two Decades of Shellfish Farming on Phytoplankton Biomass, Abundance and Productivity of a Coastal Lagoon Influenced by Upwelling. Hidrobiologica, 17, $213-224$.

[5] Moreno-Miranda, C. (2007) Variabilidad espacial de la composición taxonómica del fitoplancton en Bahía San Quintín. Tésis de Maestría, Facultad de Ciencias Marinas, U.A.B.C., Ensenada, B.C., 81.

[6] Utermöhl, H. (1958) Zur Vervollkommnung der quentitativen Phytoplankton-Methodik. Mitteilungen der International Vereinigung fur heorestische und Angewandte Limnologie, 9, 1-38.

[7] Villafañe, V. and Reid, F. (1995) Métodos de microscopia para la cuantificación del fitoplancton. In: Alveal, K., Ferreiro, M.E., Oliviera, E.C. and Ferreiro, M.A., Eds., Manual de Métodos Ficológicos, Universidad de Concepción, Concepción, 169-185.

[8] Edler, L. and Elbrächter, M. (2010) The Utermöhl Method for Quantitative Phytoplankton Analysis. Intergovernmental Oceanographic Commission of UNESCO.

[9] Mackey, M.D., Mackey, D.J., Higgins, H.W. and Wright, S.W. (1996) CHEMTAX—A Program for Estimating Class Abundances from Chemical Markers: Application to HPLC Measurements of Phytoplankton. Marine Ecology Progress Series, 114, 265-283. http://dx.doi.org/10.3354/meps144265

[10] Mackey, D.J., Higging, H.W., Mackey, M.D. and Wright, S.W. (1998) Algal Class Abundances in the Western Equatorial Pacific: Estimation from HPLC Measurements of Chloroplast Pigments Using CHEMTAX. Deep Sea Research, 45, 1141-1468.

[11] Llewellyn, C., Fishwich, J. and Blackford, J. (2005) Phytoplankton Community Assemblage in the English Channel: A Comparison Using Chlorophyll a Derived from HPLC-CHEMTAX and Carbon Derived from Microscopy Cell Counts. Journal of Plankton Research, 27, 103-119. http://dx.doi.org/10.1093/plankt/fbh158

[12] Lara-Lara, J.R. and Álvarez-Borrego, S. (1975) Ciclo anual de la clorofila y producción orgánica en la Bahía de San Quintín B.C. Ciencias Marinas, 2, 77-96.

[13] Millán-Núñez, R. and Álvarez-Borrego, S. (1978) Series de tiempo de clorofilas a, b, y c, y sus feofitinas en las bocas de dos lagunas costeras. Ciencias Marinas, 5, 41-52.

[14] Barnard, J.L. (1962) Benthic Marine Exploration of the Bahia San Quintín, Baja California, 1960-1961. Pacific Naturalist, 2, 251-269.

[15] Camacho-Ibar, V.F., Hernández-Ayón, M., Santamaría-del Angel, E., Daesslé-Heusr, W. and Zertuche-González, J.A. (2007) Relaciones de la surgencias con los stocks de carbono en Bahía San Quintín, una laguna costera del NW de México. In: Hernández de la Torre, B. and Gaxiola-Castro, G., Eds., Carbono en ecosistemas acuáticos de México, INE, SEMARNAT, CICESE, México, 355-370.

[16] Lara-Lara, J.R., Álvarez-Borrego, S. and Small, L.F. (1980) Variability and Tidal Exchange of Ecological Properties in a Coastal Lagoon. Estuarine and Coastal Marine Science, 2, 613-637. http://dx.doi.org/10.1016/S0302-3524(80)80014-4

[17] Álvarez-Borrego, S. (2004) Dinámica de nutrientes y fitoplancton en una laguna costera fuertemente afectada por surgencias costeras. Ciencias Marinas, 30, 1-19.

[18] Ribas-Ribas, M., Hernández-Ayón, J.M., Camacho-Ibar, V.F., Cabello-Pasini, A., Mejia-Trejo, A., Durazo, R., Galindo-Bect, S., Souza, A.J., Forja, J.M. and Siqueiros-Valencia, A. (2011) Effects of Upwelling, Tides and Biological Processes on the Inorganic Carbon System of a Coastal Lagoon in Baja California. Estuarine, Coastal and Shelf Science, 95, 367-376. http://dx.doi.org/10.1016/j.ecss.2011.09.017

[19] Santamaría-del-Ángel, E. (1988) Variación fitoplanctónica en Puerto Don Juan, Bahía de los Ángeles, Baja California México. Tésis de Maestría en Oceanografía Costera, Facultad de Ciencias Marinas, UABC, Ensenada, 153.

[20] Bidigare, R.R. and Trees, C.C. (2000) HPLC Phytoplankton Pigments: Sampling Laboratory Methods, and Quality Assurance Procedures. In: Fargion, G.S. and Mueller, J.L., Eds., Ocean Optics Protocols for Satellite Ocean Color Sensor Validation, 2nd Revision, Goddard Sapce Flight Center, Greenbelt, 154-161.

[21] Jeffrey, S.W., Mantoura, R.F.C. and Wright, S.W. (1997) Phytoplankton Pigments in Oceanography: Guidelines and Modern Methods. UNESCO Publishing, Paris, 661.

[22] Latasa, M., Bidigare, R.R., Ondrusek, M.E. and Kennicutt II, M.C.V. (1996) HPLC Analysis of Algal Pigments: A Comparison Exercise among Laboratories and Recommendations for Improved Analytical Performance. Marine Chemistry, 51, 315-324. http://dx.doi.org/10.1016/0304-4203(95)00056-9

[23] Lionard, M., Muylaert, K., Tackx, M. and Vyverman, W. (2008) Evaluation of the Performance of HPLC-CHEMTAX Analysis for Determining Phytoplankton Biomass and Composition in a Turbid Estuary (Schelde, Belgium). Estuarine, Coastal and Shelf Science, 76, 809-817. http://dx.doi.org/10.1016/j.ecss.2007.08.003

[24] Gordon, L.I., Jennings, J.C., Ross, A.A. and Krest, J.M. (1993) A Suggested Protocol for Continuous Flow Automated 
Analysis of Seawater Nutrients (Phosphate, Nitrate, Nitrite and Silicic Acid) in the WOCE Hydrographic Program and the Joint Global Ocean Fluxes Study. WOCE Hydrographic Program Office, Methods Manual WHPO, 91-100.

[25] Armstrong, F.A., Stearns, C.R. and Strickland, J.D. (1967) The Measurement of Upwelling and Subsequent Biological Processes by Means of the Technicon Autoanalyzer and Associated Equipment. Deep-Sea Research, 14, 381-389.

[26] Bernhardt, H. and Wilhelms, A. (1967) The Continuous Determination of Low Level Iron, Soluble Phosphate and Total Phosphate with the Autoanalyzer. Technicon Symposium, 1, 386.

[27] Zaytsev, O., Cervantes-Duarte, R., Montante, O. and Gallegos-García, A. (2003) Coastal Upwelling Activity on the Pacific Shelf of the Baja California Peninsula. Journal of Oceanography, 59, 489-502. http://dx.doi.org/10.1023/A:1025544700632

[28] Durazo, R., Ramirez-Manguilar, A.M., Miranda, L.E. and Soto-Mardones, L.A. (2010) Climatología de variables hidrográficas. In: Gaxiola-Castro, G. and Durazo, R., Eds., Dinámica del ecosistema pelágico frente a Baja Caliofrnia, 1997-2007, SEMARNAT, INE, CICESE, UABC, Mexico, 25-57.

[29] Gaxiola-Castro, G., Cepeda-Morales, J., Najera-Martinez, S., Espinoza-Carreón, T.L., De la Cruz-Orozco, M.E., SosaAvalos, R., Aguirre-Hernández, E. and Cantú-Ontiveros, J.P. (2010) Biomas y producción del fitoplancton. In: Gaxiola-Castro, G. and Durazo, R., Eds., Dinámica del ecosistema pelágico frente a Baja California, 1997-2007, SEMARNAT, INE, CICESE, UABC, Mexico, 59-85.

[30] Bouman, H.A., Platt, T., Sathyendranath, S. and Stuart, V. (2005) Dependence of Light-Saturated Photosynthesis on Temperature and Community Structure. Deep Sea Research, 52, 1284-1299. http://dx.doi.org/10.1016/j.dsr.2005.01.008

[31] Platt, T., Bouman, H., Devred, E., Fuentes-Yaco, C. and Sathyendranath, S. (2005) Physical Forcing and Phytoplankton Distributions. Scientia Marina, 69, 55-73.

[32] Barlow, R., Stuart, V., Lutz, V., Sessions, H., Sathyendranath, S. and Platt, T. (2007) Seasonal Pigment Patterns of Surface Phytoplankton in the Subtropical Southern Hemisphere. Deep Sea Research, 54, 1687-1703. http://dx.doi.org/10.1016/j.dsr.2007.06.010

[33] Daesslé, L.W., Rendón-Márquez, G., Camacho-Ibar, V.F., Gutiérrez-Galindo, E., Shumilin, E. and Ortiz-Campos, E. (2009) Geochemistry of Modern Sediments from San Quintín Coastal Lagoon, Baja California: Implication for Provenance. Revista Mexicana de Ciencias Geológicas, 26, 117-132.

[34] Severin, I., Stal, L.J. (2008) Light Dependency of Nitrogen Fixation in a Coastal Cyanobacterial Mat. International Society for Microbial Ecology Journal, 2, 1077-1088.

[35] Souchu, P., Vaquer, A., Collos, Y., Landrein, S., Deslous-Paoli, J.M. and Bibent, B. (2001) Influence of Shellfish Farming Activities on the Biogeochemical Composition of the Water Column in Thau Lagoon. Marine Ecology Progress Series, 218, 141-152. http://dx.doi.org/10.3354/meps218141

[36] Dupuy, C., Vaquer, A., Lam-Höai, T., Rougier, C., Mazouni, N., Lautier, J., Colloc, Y. and Le Gall, S. (2000) Feeding Rate of the Oyster Crassostrea gigas in a Natural Planktonic Community of the Mediterranean Thau Lagoon. Marine Ecology Progress Series, 205, 171-184. http://dx.doi.org/10.3354/meps205171

[37] Margalef, R. (1978) Life Forms of Phytoplankton as Survival Alternatives in an Unstable Environment. Oceanology Acta, 1, 493-509.

[38] Stal, L.J., Severin, I. and Bolhuis, H. (2010) The Ecology of Nitrogen Fixation in Cyanobacterial Mats. In: Hallenbeck, P.C., Ed., Recent Advances in Phototrophic Prokaryotes, Advances in Experimental Medicine and Biology, Springer New York, 31-45.

[39] Wetz, S.M., Hayes, K.C., Lewitus, A.J., Wolny, J.L. and White, D.L. (2006) Variability in Phytoplankton Pigment Biomass and Taxonomic Composition over Tidal Cycles in a Salt Marsh Estuary. Marine Ecology Progress Series, 320, 109-120. http://dx.doi.org/10.3354/meps320109

[40] Domingues, R.B., Anselmo, T.P., Barbosa, A.B., Sommer, U. and Galvão, H.M. (2010) Tidal Variability of Phytoplankton and Environmental Drivers in the Freshwater Reaches of the Guadiana Estuary (SW Iberia). International Review of Hydrobiology, 95, 352-369. http://dx.doi.org/10.1002/iroh.201011230

[41] Irigoien, X., Meyer, B., Harris, R. and Harbour, D. (2004) Using HPLC Pigment Analysis to Investigate Phytoplankton Taxonomy: The Importance of Knowing Your Species. Helgol Marine Research, 58, 77-82. http://dx.doi.org/10.1007/s10152-004-0171-9

[42] Rodríguez, F., Garrido, J.L., Crespo, B.G., Arbones, B. and Figueiras, F.G. (2006) Size Fractionated Phytoplankton Pigment Groups in the NW Iberian Upwelling System: Impact of the Iberian Poleward Current. Marine Ecology Progress Series, 323, 59-73. http://dx.doi.org/10.3354/meps323059

[43] Eker-Develi, E., Berthon, J. and Van-der-Linde, D. (2008) Phytoplankton Class Determination by Microscopic and HPLC-CHEMTAX Analyses in the Southern Baltic Sea. Marine Ecology Progress Series, 359, 69-87. http://dx.doi.org/10.3354/meps07319 
[44] Hernández-Becerril, D.U., Bravo-Sierra, E. and Ramírez-Valdéz, Y. (2001) Coccolithophorids from the West Coast of Baja California, Mexico. Hydrobiologia, 452, 31-45. http://dx.doi.org/10.1023/A:1011961325093

[45] Lepisto, L., Holopainen, A.L. (2003) Occurrence of Cryptophyceae and Katablepharids in Boreal Lakes. Hydrobiologia, 502, 307-314. http://dx.doi.org/10.1023/B:HYDR.0000004288.74485.52

[46] Aveytua-Alcázar, L., Camacho-Ibar, V.F., Souza, A.J., Allen, J.I. and Torres, R. (2008) Modelling Zostera marina and Ulva spp. in a Coastal Lagoon. Ecological Modeling, 218, 354-366. http://dx.doi.org/10.1016/j.ecolmodel.2008.07.019

[47] Jeffrey, S.W., Wright, S.W. and Zapata, M. (1999) Recent Advances in HPLC Pigment Analysis of Phytoplankton. Marine Freshwater Research, 50, 879-896. http://dx.doi.org/10.1071/MF99109

[48] Zertuche-González, J.A., Camacho-Ibar, V.F., Pacheco-Ruíz, I., Cabello-Pasini, A., Galindo-Bect, L., Guzmán-Calderón, J., Macias-Carranza, V. and Espinoza-Avalos, J. (2009) The Role of Ulva spp. As a Temporary Nutrient Sink in a Coastal Lagoon with Oyster Cultivation and Upwelling Influence. Journal Applied Phycology, 21, 729-736. http://dx.doi.org/10.1007/s10811-009-9408-y

[49] Poumian-Tapia, M. and Ibarra-Obando, S. (1999) Demography and Biomass of the Seagrass Zostera marina in a Mexican Coastal Lagoon. Estuaries, 22, 879-889. http://dx.doi.org/10.2307/1353065 